\title{
SYRINGIN IN SOME SPECIES OF THE SUBTRIBE CENTAUREINAE OF THE ASTERACEAE
}

\author{
JOANNA CIS ${ }^{1}$, GERARD NOWAK ${ }^{1}$, \\ MaŁgORZATA HoroszKIEWICZ-HaSsAN ${ }^{1}$, WANDA KISIEL ${ }^{2}$ \\ ${ }^{1}$ Department of Medicinal Plants, University of Medical Sciences \\ Mazowiecka 33, 60-623 Poznan, Poland \\ 2 Department of Phytochemistry, Institute of Pharmacology \\ Polish Academy of Sciences \\ Smetna 12, 31-343 Cracow, Poland
}

(Received: July 4, 2002. Accepted: November 20, 2002)

\begin{abstract}
The occurrence of syringin in eight out of ten investigated plant species of the subtribe Centaureinae (Asteraceae) was reported. The compound was isolated from aerial parts of the plants by silica gel column chromatography of methanol extracts. Contents of syringin varied from 0.001 to $0.1 \%$ of the dried plant material. Centaurea bella Trautv. appeared to be the best source of this compound $(0.1 \%$ dry wt.). Syringin has been reported for the first time from these plant species.
\end{abstract}

KEY WORDS: syringin, phenylpropanoid glucoside, Centaureinae, Asteraceae, chemotaxonomy.

\section{INTRODUCTION}

The subtribe Centaureinae of the tribe Carduae comprises Centaurea and Serratula, and other small genera closely related to Centaurea, including Acroptilon and Leuzea. The large genus Centaurea sensu lato (c.a. 500 species) was divided into subgenera (e.g. Psephellus) and sections (e.g. Chartolepis, Grossheimia) (Bremer 1994). In most chemosystematic studies of plant species from the Centaureinae sesquiterpene lactones have been analysed. The compounds have proven to be reliable taxonomic markers within the family Asteraceae. We have studied the occurrence of the phenylpropanoid glucoside syringin (sinapyl alcohol-4-O- $\beta$-D-glucopyranoside) (Fig. 1) in ten species of different taxa of the subtribe Centaureinae, i.e. Acroptilon repens (L.) DC., Centaurea bella Trautv., Centaurea crocodylium L., Centaurea cyanus L., Chartolepis pterocaula (Trautv.) Czer., Grossheimia macrocephala (Muss.Puschk.) Sosn. et Takht., Leuzea rhapontica subsp. bick-

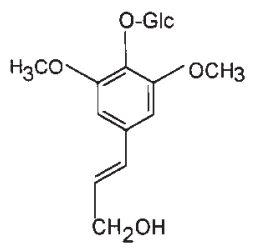

Fig. 1. Chemical structure of syringin $(\mathrm{Glc}=\beta$-D-glucopyranosyl $)$. nellii (Briq.) J. Holub, Psephellus dealbatus (Willd.) Boiss., Psephellus declinatus (MB.) C. Koch. and Serratula wolffii Andrae. A semi-quantitative analysis of syringin which might yield additional characters for differentiating the investigated taxa was also performed. So far, syringin has not been isolated from these plants. The compound, first reported from Syringa vulgaris L. by Meillet in 1841, was later found in other plants, including the medicinal plant Eleutherococcus senticosus (Widholz et al. 1976). Syringin was found to possesses an immunomodulatory activity and anti-allergic effect (Cho et al. 2001). It also showed a significant inhibitory effect on bone resorption (Li et al. 1998), anti-inflammatory activity (Lanza et al. 2001) and a mild inhibitory effect of nitric oxide synthase activity (Park et al. 1996). Additionally, it possesses a potent cytotoxic effect on several tumour cell lines (Park et al. 1999; Kim et al. 1999), and hypotensive activity (Ahmad et al. 1995).

\section{MATERIAL AND METHODS}

\section{Plant material}

Aerial parts of the above-mentioned ten plant species were collected in June-August 2001 from plants at the flowering stage. The plants were cultivated in the Garden of Medicinal Plants of the University of Medicinal Sciences in Poznan. 


\section{Extraction, isolation and identification of syringin.}

Dried aerial parts of Centaurea bella Trautv. (500 g) were cut into small pieces and exhaustively extracted with methanol at room temperature. The residue obtained after evaporation of the solvent under reduced pressure was chromatographed on a silica gel (Merck, Art. 7729) column using a chloroform-methanol mixture (12:1) as eluent. Relevant fractions containing syringin, as shown by TLC, were combined and further purified on a silica gel (Merck, Art. 5553) column. The column eluted with the same solvent mixture yielded syringin (50 mg), m.p. $191^{\circ} \mathrm{C}\left(188-190^{\circ} \mathrm{C}\right.$ cited by Wagner 1982$) .{ }^{1} \mathrm{H}-\mathrm{NMR}$ (500.13 MHz, CD 3 OD) $\delta: 6.74$ (2H, s, H-2 and H-6), 6.55 $(1 \mathrm{H}$, br $d, J=15.8 \mathrm{~Hz}, \mathrm{H}-7), 6.32(1 \mathrm{H}, d t, J=15.8$ and 5.6 $\mathrm{Hz}, \mathrm{H}-8), 4.21(2 \mathrm{H}, d d, J=5.6$ and $1.5 \mathrm{~Hz}, \mathrm{H}-9), 3.85(6 \mathrm{H}$, $s,-\mathrm{OMe}), 4.86(1 \mathrm{H}, d, J=7.6 \mathrm{~Hz}, \mathrm{H}-1 \mathrm{Glc}), 3.47(1 \mathrm{H}, d d$, $J=9.5$ and $7.6 \mathrm{~Hz}, \mathrm{H}-2 \mathrm{Glc}), 3.40$ (2H, $m, \mathrm{H}-3 \mathrm{Glc}$ and $\mathrm{H}-$ 4 Glc), 3.20 (1H, $m, \mathrm{H}-5 \mathrm{Glc}), 3.65(1 \mathrm{H}, d d, J=12.0$ and $5.2 \mathrm{~Hz}, \mathrm{H}-6 \mathrm{Glc}), 3.77$ (1H, $d d, J=12.0$ and $2.3 \mathrm{~Hz}, \mathrm{H}-6$ ' Glc). The identity of syringin was confirmed by co-chromatography with an authentic sample and by comparison of its ${ }^{1} \mathrm{H}$ NMR data with those in the literature (Greca et al. 1998). The compound was easily detectable on silica gel TLC plates (Merck, Art. 1.05748, chloroform-methanol $\left.4: 1, \mathrm{R}_{\mathrm{f}}=0.3\right)$ in UV light and after spraying with anisaldehyde reagent followed by heating (dark blue colour) (Fig. 2).

The same procedures were used for separation of syringin from: Acroptilon repens, Centaurea crocodylium, Chartolepis pterocaula, Grossheimia macrocephala, Leuzea rhapontica subsp. bicknellii, Psephellus dealbatus and Psephellus declinatus (Fig. 2). Yields of the isolated compound from the plant materials are given in Table 1.

\section{RESULTS AND DISCUSSION}

Our chemical study of methanolic extracts from aerial parts of ten plant species belonging to the subtribe Centaureinae led to the isolation of syringin from all but two extracts (Table 1). Syringin was absent from Centaurea cyanus and Serratula wolffii, and occurred as a minor constituent (0.001-0.006\% of the dried plant material) in Acroptilon repens, Centaurea crocodylium, Grossheimia macrocephala, Leuzea rhapontica subsp. bicknellii, Psephellus dealbatus, Psephellus declinatus. From Chartolepis pterocau-

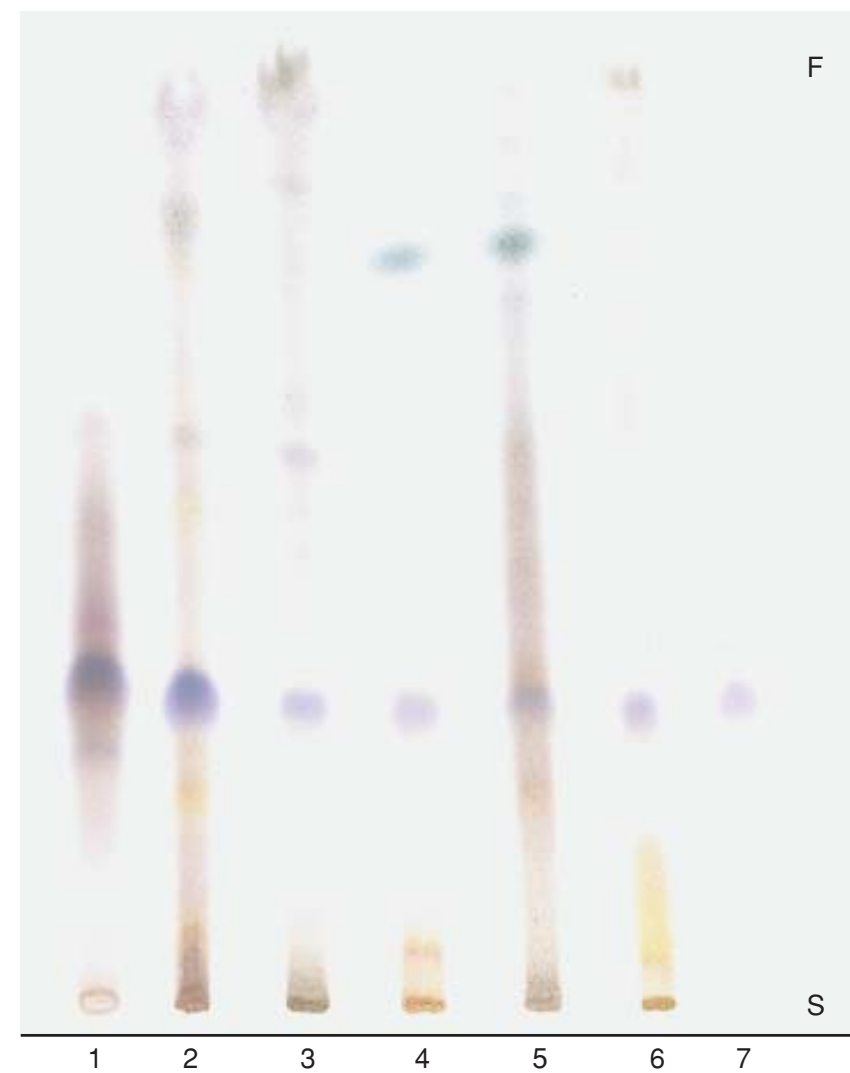

Fig. 2. Chromatogram of methanolic extracts from investigated genus and syringin.

Methanolic extracts of: 1 - Acroptilon repens; 2 - Centaurea bella; 3 Chartolepis pterocaula, 4 - Grossheimia macrocephala; 5 - Leuzea rhapontica subsp. bicknellii; 6 - Psephellus declinatus; 7 - syringin. S start; F - finish. Adsorbent: silica gel. Mobile phase: chloroform-methanol 4:1. Reagent: anisaldehyde.

la and especially from Centaurea bella it was isolated in higher amounts (0.03 and $0.1 \%$, respectively).

In our previous papers (Cis et al. 2000; Daniewski et al. 1982; Horoszkiewicz-Hassan and Nowak 2001; Nowak et al. 1986; Nowak 1993), it could be demonstrated that the above-mentioned plant species, except for Centaurea cyanus and Serratula wolffii, accumulate guaiane- and/or germacrane-type sesquiterpene lactones. Furthermore, it could be shown that Centaurea bella possesses the highest capacity of producing not only syringin, but also sesquiterpene

TABLE 1. Occurrence of syringin in some species of the subtribe Centaureinae.

\begin{tabular}{|c|c|c|c|}
\hline Taxon & $\begin{array}{c}\text { Content }{ }^{*} \text { of syringin } \\
\text { (\% dry wt. })\end{array}$ & $\begin{array}{l}\text { Accompanying } \\
\text { sesquiterpene lactones }\end{array}$ & Literature \\
\hline Acroptilon repens (L.) DC. & 0.003 & 3 guaianolides & Fisher N.H. et al. 1979 \\
\hline Centaurea bella Trautv. & 0.1 & 25 guaianolides and 1 germacranolid & Nowak G. 1993 \\
\hline Centaurea cyanus $\mathrm{L}$. & not detectable & - & \\
\hline Centaurea crocodylium L. & 0.001 & 2 germacranolides & $\begin{array}{l}\text { Horoszkiewicz-Hassan M., } \\
\text { Nowak G. } 2001\end{array}$ \\
\hline Chartolepis pterocaula (Trautv.) Czer. & 0.03 & 9 guaianolides & Nowak G. et al. 1986 \\
\hline Grossheimia macrocephala (Muss. - Puschk.) Sosn. et Takht. & 0.001 & 4 guaianolides & Daniewski W. et al. 1982 \\
\hline Leuzea rhapontica subsp. bicknellii (Briq.) J. Holub & 0.001 & 5 guaianolides & Cis J. et al. 2000 \\
\hline Psephellus dealbatus (Willd.) Boiss. & 0.002 & 7 guaianolides & Nowak G. et al. 1986 \\
\hline Psephellus declinatus (MB.) C. Koch. & 0.006 & 3 guaianolides & Nowak G. et al. 1986 \\
\hline Serratula wolffii Andrae & not detectable & - & \\
\hline
\end{tabular}

*Estimated on the basis of isolated amounts of syringin from dried plant materials. 
lactones. From this plant 26 sesquiterpenoids were isolated. Chartolepis pterocaula yielded nine sesquiterpenoids and the remaining species less than eight compounds of this group. It seems to be a positive correlation of syringin with sesquiterpene lactones in the investigated plant species.

\section{LITERATURE CITED}

AHMAD M., AFTAB K. 1995. Hypotensive action of syringin from Syringa vulgaris. Phytotherapy Research 9: 452-454.

BREMER K. 1994. Asteraceae: Cladistics \& Classification. Timber Press, Portland, Oregon, pp. 112-156.

CHO J.Y., NAM K.H., KIM A.R., PARK J., YOO E.S., BAIK K.U., YU Y.H., PARK M.H. 2001. In vitro and in vivo immunomodulatory effects of syringin. J. Pharm. Pharmacol. 53: 1287-1294.

CIS J., NOWAK G., GRABARCZYK H. 2000. Preliminary identification of unknown and well - known guaianolides of the genus Leuzea DC. $2^{\text {nd }}$ International Symposium on Chromatography of Natural Products in Kazimierz Dolny. Book of Abstracts, p. 61

DANIEWSKI W., WAWRZUŃ A., BŁOSZYK E., DROŻDŻ B., HOLUB M. 1982. Sesquiterpenic lactones from Grossheimia macrocephala. Structure of grosheiminol. Coll. Czechoslov. Chem. Commun. 47: 3160-3163.

GRECA M.D., FERRARA M., FIORENTINO A., MONACO P., PREVITERA L. 1998. Antialgal compounds from Zantedeschia aethiopica. Phytochemistry 49: 1299-1304.

HOROSZKIEWICZ-HASSAN M., NOWAK G. 2001. Germakranolidy w Centaurea crocodylium L. Herba Polonica 47: 122-124.

KIM D.H., LEE K.T., BAE E.A., HAN M.J., PARK H.J. 1999. Metabolism of liriodendroin and syringin by human intestinal bacteria and their relation to in vitro cytotoxicity. Archives of Pharmaceutical Research. 22: 30-34.

LANZA A.M.D., MARTINEZ M.J.A., MATELLANO L.F., CARRETERO C.R., CASTILLO L.V., SEN A.M.S., BENITO P.B. 2001. Lignan and Phenylpropanoid Glycosides from Phillyrea latifolia and their in vitro Anti-inflammatory Activity. Planta Medica. 67: 219-223.

LI H., MIYAHARA T., TEZUKA Y., NAMBA T., NEMOTO N., TONAMI S., SETO H., TADA T., KADOTA S. 1998. The effect of Kampo formulae on bone resorption in vitro and in vivo. I. Active constituents of Tsu-kangan. Biological and Pharmaceutical Bulletin 21: 1322-1326.

PARK H.J., JUNG W.T., BASNET P., KADOTA S., NAMBA T. 1996. Syringin 4-O- $\beta$-glucoside, a new phenylpropanoid glycoside, and costunolide, a nitric oxide synthase inhibitor, from the stem bark of Magnolia sieboldii. Journal of Natural Products 59: 1128-1130.

PARK H.J., LEE M.S., LEE K.T., SOHN I.C., HAN Y.N., MIYAMOTO K.I. 1999. Studies on constituents with cytotoxic activity from the stem bark of Syringa velutina. Chemical and Pharmaceutical Bulletin 47: 1029-1031.

NOWAK G., DROŻDŻ B., HOLUB M., ŁAGODZIŃSKA A. 1986. Sesquiterpene lactones XXXIII. Guaianolides in the subgenus Psephellus (Cass.) Schmalh., genus Centaurea L. Acta Soc. Bot. Pol. 55: 629-637.

NOWAK G. 1993. Chromatography of twenty six sesquiterpene lactones from Centaurea bella. Chromatographia 35: 325-328.

WAGNER H., HEUR Y.H., OBERMEIER A., TITTEL G., BLADT S. 1982. Die DC-and HPLC-Analyse der Eleutherococcus Droge. Planta Medica 44: 193-198.

WIDHOLZ M., BUDAVARI S., STROUMTSOS L.Y., FERTIG M.N. 1976. The Merck index-An encyclopedia of chemicals and drugs, Merck \& CO., New York, USA. p. 1168.

\title{
SYRINGINA W NIEKTÓRYCH GATUNKACH PODPLEMIENIA CENTAUREINAE (ASTERACEAE)
}

\author{
STRESZCZENIE
}

Stwierdzono występowanie syringiny w 8 spośród 10 przebadanych gatunków roślin z podplemienia Centaureinae (Asteraceae). Związek ten wyodrębniono $\mathrm{z}$ metanolowych wyciągów nadziemnych części roślin metodą chromatografii kolumnowej na żelu krzemionkowym. Zawartości syringiny wahały się od 0,001 do 0,1\% suchej masy materiału roślinnego. Centaurea bella Trautv. okazała się najlepszym źródłem tego związku (0,1\% suchej masy). Występowanie syringiny w tych roślinach stwierdzono po raz pierwszy.

SŁOWA KLUCZOWE: syringina, glukozyd fenylpropanowy, Centaureinae, Asteraceae, chemotaksonomia. 